\title{
北海道のアライグマからのレプトスピラの分離と抗体調査
}

吉識綾子 ${ }^{1} \cdot$ 的場洋平 $^{2} \cdot$ 浅川満彦 $^{2} \cdot$ 高橋樹史 $^{1} \cdot$ 中野良宣 $^{1} \cdot$ 菊池直哉 $^{1 *}$

${ }^{1}$ 酪農学園大学獣医学部獣医学科獣医細菌学教室,

2 酪農学園大学獣医学部獣医学科獣医寄生虫学教室

069-8501 江別市文京台緑町 582

\section{Isolation of Leptospira from Raccoons and Serological Survey of Leptospirosis in Hokkaido, Japan}

\author{
Ayako YOSHIKI ${ }^{1}$, Yohei MATOBA ${ }^{2}$, Mitsuhiko ASAKAWA ${ }^{2}$, Tatsufumi TAKAHASHI ${ }^{1}$, \\ Yoshinori NAKANO ${ }^{1}$ and Naoya $\mathrm{KIKUCHI}^{1 *}$ \\ ${ }^{1}$ Department of Veterinary Bacteriology School of Veterinary Medicine, Rakuno Gakuen University \\ ${ }^{2}$ Veterinary Parasitelogy, School of Veterinary Medicine, Rakuno Gakuen University \\ 582 Bunkyodai-midorimachi, Ebetsu, Hokkaido 069-8501, Japan \\ (Recieved 27 $7^{\text {th }}$ August, 2011/Accepted $1^{\text {st }}$ October, 2011)
}

\begin{abstract}
Summary
A bacterial and serological survey of leptospirosis in raccoons (Procyon lotor) was performed in central Hokkaido, Japan. Leptospira was isolated from 10 (3.9\%) of 259 raccoons captured in central Hokkaido. Leptospira DNA was also detected by PCR in samples from 60 (23.2\%) raccoons, and leptospiral antibodies were detected in 63 (24.5\%) raccoons. The positive rate was highest for serovar Autumnalis (10.8\%), followed serovar Canicola, Australis, Ballum, Hebdomadis and Pyrogenes (4.6\%). The present study revealed that Leptospira is widespread in raccoons in Hokkaido, and raises concerns regarding the likelihood of humans and domestic animals acquiring, leptospirosis through contact with raccoons.
\end{abstract}

Keywords : Raccoons, Leptospira, Isolation, Antibody, Japan

\section{序 文}

レプトスピラ症は病原性レプトスピラの感染に起因する 人獣共通感染症であり, 世界各国で発生が報告されている。 日本では, 人においては感染症の予防及び感染症の患者に 対する医療に関する法律（感染症法）で第 4 類に, 牛, 豚, 犬においては家畜伝染病予防法で届出伝染病に指定されて いる。レプトスピラは自然界に広く存在し, 特にネズミなど のげっ歯類が保菌動物として重要な役割を占めている ${ }^{13,17) 。 ~}$

連絡先 : 菊池直哉*

酪農学園大学獣医学部獣医細菌学教室

干069-8501 江別市文京台緑町 582

Tel : 011-388-4729 ; Fax : 011-387-5890

E-mail : nkikuchi@rakuno.ac.jp
これらの動物の多くは不顕性のまま経過し，長期にわたり 尿中に菌を排出し, 川や土壤などの環境を污染し, そこに 人や家畜などが入り込む事により水などを介して皮膚や粘 膜などから経皮的に，あるいは污染飼料や感染動物の捕食 などにより経口的に感染が起こる ${ }^{11,17)}$ 。生体内に侵入した レプトスピラは血中で増殖し, 肝臓, 腎臓などの各臓器に 運ばれる。レプトスピラに対する抗体の産生により血中か らレプトスピラは排除されるが, 腎尿細管で潜伏, 増殖す ることができ, 腎尿細管から尿中に排泄され, 次なる感染 源となる ${ }^{3)}$ 。

人のレプトスピラ症では, 発熱, 黄疸, 出血, 蛋白尿, 筋 肉痛, 頭痛, 腎不全, 髄膜炎などの臨床症状がみられ, 重 症の場合は死亡する。牛や犬などの動物が感染すると黄疸, 貧血, 血色素尿などの症状を示し, 動物種によっては流産 
を起こす ${ }^{25)}$ 。一方，野生動物においてもレプトスピラ症が あることが報告されている1, 2, 13, 14, 20, 22, 24)。北米では, アラ イグマにおける Leptospira interrogans を保有していると報 告されており, 主な血清型としては Icterohaemorrhagiae, Pomona, Bratislava, Grippotyphosa, Hardjo, Autumnalis な どがある ${ }^{7,14,16,18,21,23) 。}$

最近北海道を含め全国的に野生化したアライグマが増加 の一途を辿っている ${ }^{8,9,10)}$ 。アライグマは生息域を拡げ，畑

地, 牛舎, 民家などに慨を求めて侵入することもあり, ヒ ト, イヌ, 家畜などと接触する機会が増加しているため, アライグマのレプトスピラの浸潤状況を知ることは重要で ある。日本における調査では, 神奈川県と長崎県のアライ グマから L. interrogans が分離された ${ }^{12)}$ 。しかし, 多数の アライグマが生息し農業被害も甚大な北海道においては調 査されていない。本研究では北海道に生息するアライグマ を対象に病原学的および血清学的調査を実施し本症の浸潤 状況を調べた。

\section{材料と方法}

\section{1. 供試材料}

2003 年 5 月から同年 9 月の間に, 北海道石狩 - 空知 ・ 胆振地方において捕獲された 259 頭のアライグマを用い た。成獣と幼獣の区別は歯の状態及び胎盤痕の有無によ り確認した。さらに臼歯根の年輪により 1 歳以上かつ体重 $4 \mathrm{~kg}$ 以上を成獣とし，さらに雌の場合は胎盤痕および泌乳 の認められるものを成獣とした。本研究では捕獲されたも

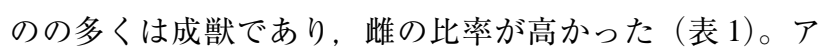
ライグマはその日のうちに剖検され, 肝臓, 腎臓, 尿, 血 液が無菌的に採取された。

\section{2. レプトスピラの分離}

1）レプトスピラ分離用培地

菌の生存期間と発育を高める目的で寒天を $0.1 \%$ 含む $100 \mu \mathrm{g} / \mathrm{ml}$ 5-fluorouracil 添加 EMJH 培地を分離培地として 使用しだ゚。

2）レプトスピラ培養方法

無菌的に採取した肝臓と腎臓をマイクロチューブ内で乳 剂にし, 滅菌生理食塩水 $1 \mathrm{ml}$ に懸濁し, $400 \times \mathrm{g}$ で 2 分間 遠心した。その上清を $700 \mu \mathrm{l}$ とり，14,080×g で 5 分間遠 心後, 沈椬を培地に接種した。尿はマイクロチューブに $2 \mathrm{ml}$ とり $14,080 \times \mathrm{g}$ で 5 分間遠心後, 上清を捨て沈椬を培 地に接種した。尿が採取できなかった時は無菌的に採取し た膀胱に滅菌生理食塩水を $5 \mathrm{ml}$ 注入後, $2 \mathrm{ml}$ 回収し尿と 同じ処理を行った。 $30^{\circ} \mathrm{Cで} 6$ ケ月間培養し, 6 ケ月経過し ても菌の発育がみられないものを陰性とした。

\section{3. nested PCR 法によるレプトスピラ DNA の検出}

1) ゲノム DNA 抽出試料の調整
表 1 本研究において使用したアライグマの捕獲地域と概要

\begin{tabular}{|c|c|c|c|c|c|}
\hline \multirow{2}{*}{ 地域 } & \multirow{2}{*}{ 検査頭数 } & \multicolumn{2}{|c|}{ 生育状態 } & \multicolumn{2}{|c|}{ 性別 } \\
\hline & & 成獣 & 幼獣 & 雄 & 雌 \\
\hline 石狩 & 88 & 49 & 39 & 36 & 52 \\
\hline 空知 & 154 & 104 & 50 & 68 & 86 \\
\hline 胆振 & 17 & 17 & 0 & 7 & 10 \\
\hline 総計 & 259 & 170 & 89 & 111 & 148 \\
\hline
\end{tabular}

\section{a. 肝臓および腎臓}

無菌的に組織を $5 \mathrm{~mm}$ 角に切り, マイクロチューブに入 れホモジナイザーで乳剤にした後, $1 \mathrm{ml}$ の滅菌生理食塩水 を加えて調整した。調整乳剤は $14,080 \times g, 5$ 分間遠心によっ て上清を除去し沈椬を残した。その後, DNA 抽出キット, (Sepa Gene, 三光純薬株式会社) を用い, 添付の操作説明 書に従ってDNAの抽出と精製を行い, DNA ペレットを $50 \mu \mathrm{l}$ の TE 緩衝液に浮遊させ, PCR 反応用試料とした。

b. 尿

エッペンチューブに尿 $1.0 \mathrm{ml}$ を入れ $14,080 \times \mathrm{g}, 5$ 分間 遠心後, 上清を除去し, 沈椬を用いて, 肝蔵, 腎臓と同様 に処理を行った。

2) nested-PCR 反応

一次プライマーは Gravekamp ら ${ }^{6)}$ の G1/G2 プライマー (5'-CTGAATCGCTGTATAAAAGT-3', 5'-GAAGGCTGGTAAACAAAAGG-3') を, 二次プライマーは古谷ら ${ }^{5)}$ のプライマー int- G1/G2 (5'-CGCATGATACCAAATCTGAG-3', 5'-AACTGAGAACCGGACTTGGT-3') を用い nested-PCR を 行った。

\section{4. 顕微鏡学的凝集反応（凝集反応）}

\section{1）抗原の調整}

凝集反応では, L. interrogans, L. borgpetersenii および L. kirschneri の 11 血清型を凝集反応用抗原とした（表 2)。抗 原は $\mathrm{ENJH}$ 培地を用い, $30^{\circ} \mathrm{C}$ 6〜9 日培養後, 菌数を 1〜2 $\times 10^{8} \mathrm{cell} / \mathrm{ml}$ に調整したものである。

2) 抗体価測定

被検血清と等量の抗原液を加え, 最終希釈倍数を 25 倍, 50 倍, 100 倍とした。ミキサーでよく混和した後, 蒸発を 防ぎ $30^{\circ} \mathrm{C} 3$ 時間反応させた後, 顕微鏡下で観察した。菌 の凝集が見られた場合, または対照培養溶液よりも菌数が 著しく減少している場合を凝集陽性とした。最終血清希釈 倍数が 100 倍以上で凝集を示した血清については, さらに 100〜1,600 倍に希釈し同様に凝集反応を行った。凝集を示 した最終希釈倍数の逆数を抗体価とし, 凝集価 100 倍以上 を示したものをレプトスピラ抗体陽性とした。 
表 2 顕微鏡学的凝集反応において抗原として用いた Leptospira 菌種および血清型

\begin{tabular}{lll}
\hline 菌種 & \multicolumn{1}{c}{ 血清型 } & \multicolumn{1}{c}{ 菌株名 } \\
\hline L. interrogans & Autumnalis & Akiyami A \\
& Australis & Ballico \\
& Bratislava & Bratislava \\
& Hebdomadis & Hebdomadis \\
& Icterohaemorrhagiae & RGA \\
& Pomona & Pomona \\
& Hardjo & Hardjoprajitro \\
& Canicola & Hond Utrecht IV \\
& Pyrogenes & Salinem \\
L. borgpetersenii & Ballum & Mus 127 \\
& Grippotyphosa & Moskva V \\
\hline
\end{tabular}

\section{5. 統計処理}

統計処理は $\chi^{2}$ 検定を行い, $5 \%$ 以下を有意差とみなした。

\section{成 績}

\section{1. 肝臓, 腎臓および尿からのレプトスピラの分離}

2003 年に捕獲されたアライグマ全 259 頭中, 10 頭 (3.9\%) からレプトスピラが分離された（表 3)。臓器別では，肝 臓 2 例 $(0.8 \%)$, 腎臓 9 例 (3.5\%), 尿 1 例（0.4\%）から レプトスピラが分離された。このうち 2 頭は肝臓と腎蔵の 両方から分離された。レプトスピラが分離された 10 例中 成獣 7 例, 幼獣 3 例, また雄 6 例, 雌 4 例で, 成獣と幼獣 間および雌雄間に差は認められなかった。また，地域的に も差は認められなかった。レプトスピラの発育が確認され るまでの培養期間は長く，2３週間で分離できたものが 10 例中 6 例であり，2 例は分離に 10 週間を要した。

\section{2. nested PCR 法によるレプトスピラ DNA の検出}

アライグマ 259 頭の肝臓, 腎臓および尿からの検体につ いて nested PCR を行った。その結果, 60 頭 (23.2\%) から レプトスピラ DNA が検出された(表 3)。肝臓 26 例 (10\%), 腎臓 33 例 $(12.7 \%)$ ，尿 28 例（10.8\%）からレプトスピラ 特異的 DNA が検出された。肝臓, 腎臓および尿からの検 出率に差はみられなかったが, 腎臓あるいは尿の泌尿器系 から検出された例が 60 例中 46 例であり, 肝臓に比較し検 出率が高かった。肝臓，腎臓および尿の全てから検出され たものは 4 例であった。PCRの結果を成獣，幼獣別にみ てみると，成獣では 170 頭中 46 頭 $(27.1 \%)$ が，幼獣で は 89 頭中 14 頭 $(15.7 \%)$ が陽性を示し，幼獣よりも成獣 の方が高い陽性率を示した。地域別では胆振地方における 陽性率が石狩・空知地方に比較して高かった（表 4)。
表 3 アライグマの臓器からのレプトスピラの分離および nested-PCR によるレプトスピラ DNA の検出

\begin{tabular}{|c|c|c|c|c|c|}
\hline \multirow[b]{2}{*}{ 検出方法 } & \multirow{2}{*}{$\begin{array}{l}\text { 検査 } \\
\text { 頭数 }\end{array}$} & \multirow{2}{*}{$\begin{array}{c}\text { 陽性数 } \\
(\%)\end{array}$} & \multicolumn{3}{|c|}{ レプトスピラ検出材料 } \\
\hline & & & $\begin{array}{c}\text { 肝臓 } \\
(\%)\end{array}$ & $\begin{array}{l}\text { 腎臓 } \\
(\%)\end{array}$ & $\begin{array}{l}\text { 尿 } \\
(\%)\end{array}$ \\
\hline $\begin{array}{c}\text { レプトスピラ } \\
\text { の分離 }\end{array}$ & 259 & $\begin{array}{c}10 \\
(3.9)\end{array}$ & $\begin{array}{c}2 \\
(0.8)\end{array}$ & $\begin{array}{c}9 \\
(3.5)\end{array}$ & $\begin{array}{c}1 \\
(0.4)\end{array}$ \\
\hline $\begin{array}{l}\text { PCR による } \\
\text { DNA の検出 }\end{array}$ & 259 & $\begin{array}{c}60 \\
(23.2)\end{array}$ & $\begin{array}{c}26 \\
(10.0)\end{array}$ & $\begin{array}{c}33 \\
(12.7)\end{array}$ & $\begin{array}{c}28 \\
(10.8)\end{array}$ \\
\hline
\end{tabular}

表 4 成獣・幼獣別，雌雄別および地域別における nested PCR によるレプトスピラ DNA の検出

\begin{tabular}{cccl}
\hline 区分 & 検査頭数 & 陽性数 & $(\%)$ \\
\hline 成獣 & 170 & 46 & $(27.1)^{*}$ \\
幼獣 & 89 & 14 & $(15.7)^{*}$ \\
小計 & 259 & 60 & $(23.2)$ \\
\hline 雄 & 111 & 26 & $(23.4)$ \\
雌 & 148 & 34 & $(23.0)$ \\
小計 & 259 & 60 & $(23.2)$ \\
\hline 石狩 & 88 & 20 & $(22.7)^{*}$ \\
空知 & 154 & 32 & $(20.8)^{\#}$ \\
胆振 & 17 & 8 & $(47.1)^{* *}$ \\
小計 & 259 & 60 & $(23.2)$ \\
\hline
\end{tabular}

$*^{*}: \mathrm{P}<0.05$

\section{3. 凝集反応によるレプトスピラ抗体価の測定}

259 頭中 255 頭から血清が得られ，それらについて 11 種の血清型のレプトスピラを用いて MAT を行った。その 結果, 63 頭 (24.3\%) でいずれかの血清型に対しての抗体 が確認された（表 5)。地域的には，検査例数は少なかっ たが胆振地方では 17 頭中 8 頭 (48.6\%) が陽性で, 他地域 と比較し高い陽性率を示した。陽性を示した血清型は多様 性を示し，その中で最も陽性率が高かったのは Autumnalis (10.8\%) であり，次いで, Canicola (5.4\%), であった。 Icterohaemorrhagiae, Australis, Pyrogenesに対しても抗体 価の高い例が多くみられた。Grippotyphosaに対する抗体 は認められなかった。胆振地方における抗体陽性率は, ほ とんどの血清型において他地域より高かった。

成獣と幼獣別にみてみると, 成獣では全 170 頭中 51 頭 (42.9\%) が陽性を示したのに対し，幼獣は全 85 頭中 12 頭（14.1\%）が陽性を示した。このように幼獣よりも成獣 の方が，陽性率が高く， PCRの結果と同様であった。 
表 5 アライグマからの MAT によるレプトスピラ抗体の地域別検出と血清型の分布

\begin{tabular}{|c|c|c|c|c|c|c|c|c|c|c|c|c|}
\hline \multirow{2}{*}{ 地域 } & \multirow{2}{*}{ 検査頭数 } & \multirow{2}{*}{$\begin{array}{c}\text { 陽性数 } \\
(\%)\end{array}$} & \multicolumn{9}{|c|}{ 血清型 } & \multirow[b]{2}{*}{ Grippo. } \\
\hline & & & Autum. & Australis & Hebdo. & Ictero. & Pomona & Hardjo & Canicola & Pyrogenes & Ballum & \\
\hline 石狩 & 84 & $\begin{array}{c}15 \\
(17.9)^{*}\end{array}$ & $\begin{array}{c}2 \\
(2.3)\end{array}$ & $\begin{array}{c}2 \\
(2.3)\end{array}$ & $\begin{array}{c}1 \\
(1.1)\end{array}$ & $\begin{array}{c}5 \\
(5.7)\end{array}$ & 0 & $\begin{array}{c}1 \\
(1.1)\end{array}$ & $\begin{array}{c}5 \\
(5.7)\end{array}$ & $\begin{array}{c}3 \\
(3.4)\end{array}$ & $\begin{array}{c}2 \\
(2.3)\end{array}$ & 0 \\
\hline 空知 & 154 & $\begin{array}{c}40 \\
(25.6)\end{array}$ & $\begin{array}{c}22 \\
(14.2)\end{array}$ & $\begin{array}{c}7 \\
(4.5)\end{array}$ & $\begin{array}{c}10 \\
(6.5)\end{array}$ & $\begin{array}{c}5 \\
(3.2)\end{array}$ & $\begin{array}{c}7 \\
(4.5)\end{array}$ & $\begin{array}{c}5 \\
(3.2)\end{array}$ & $\begin{array}{c}5 \\
(3.2)\end{array}$ & $\begin{array}{c}6 \\
(3.9)\end{array}$ & $\begin{array}{c}6 \\
(3.9)\end{array}$ & 0 \\
\hline 胆振 & 17 & $\begin{array}{c}8 \\
(48.6)\end{array}$ & $\begin{array}{c}4 \\
(23.5)\end{array}$ & $\begin{array}{c}3 \\
(17.6)\end{array}$ & $\begin{array}{c}1 \\
(5.9)\end{array}$ & $\begin{array}{c}1 \\
(5.9)\end{array}$ & $\begin{array}{c}1 \\
(5.9)\end{array}$ & 0 & $\begin{array}{c}4 \\
(23.5)\end{array}$ & $\begin{array}{c}3 \\
(17.6)\end{array}$ & $\begin{array}{c}4 \\
(23.5)\end{array}$ & 0 \\
\hline 計 & 255 & $\begin{array}{c}63 \\
(24.7)^{*}\end{array}$ & $\begin{array}{c}28 \\
(10.8)\end{array}$ & $\begin{array}{c}12 \\
(4.6)\end{array}$ & $\begin{array}{c}12 \\
(4.6)\end{array}$ & $\begin{array}{c}11 \\
(4.2)\end{array}$ & $\begin{array}{c}8 \\
(3.1)\end{array}$ & $\begin{array}{c}6 \\
(2.3)\end{array}$ & $\begin{array}{c}14 \\
(5.4)\end{array}$ & $\begin{array}{c}12 \\
(4.6)\end{array}$ & $\begin{array}{c}12 \\
(4.6)\end{array}$ & 0 \\
\hline
\end{tabular}

Autum. : Autumnalis, Hebdo. : Hebdomadis, Ictero. : Icterohaemorrhagiae, Grippo. : Grippotyphosa 陽性 : 抗体価 100 倍以上

* : $\mathrm{P}<0.05$

\section{考 察}

北海道での最初のアライグマの野生化は, 1979 年に恵 庭市で飼育されていた約 10 頭のアライグマが逃亡し，こ れらが酪農地帯に定着したのが始まりと考えられている ${ }^{10)}$ 。 アライグマは本来, 日本には生息しない北米原産の動物で ある。それが, ペット飼育用として輸入されるようにな り，逃亡や飼いきれず捨てることなどが続出し野生化につ ながったと考えられている。アライグマは繁殖能力が強 い, 食性の幅が広い, 幅広い気候条件に適応するなどの特 性から北海道だけでなく, 日本各地で野生化し, 増加して いる ${ }^{8,9,10)}$ 。

海外ではアライグマのレプトスピラ症が報告されてい る る $^{2,14,16,18,21,23)}$ 。しかし日本では，アライグマが本来日本 に生息しない移入動物であることからアライグマのレプト スピラ症についての報告は少ない。アライグマは増加し, 農家の納屋に住み着く, 畑で作物を荒らすなど, ヒト, イ ヌ，家畜などとの接触の機会も増加しているのでアライグ マの本症の浸潤状況を知ることは重要である。本調査にお いてアライグマにおけるレプトスピラの病原学的および血 清学的検索を行った結果, 本症が広く浸潤していることが 明らかになった。

捕獲されたアライグマの肝蔵, 腎蔵および尿からレプト スピラ検索の結果， 259 頭中 10 頭 (3.9\%) からレプトス ピラが分離された。日本国内ではこれまで神奈川県の野生 化したアライグマと長崎県の野外展示施設のアライグマか ら計 3 株の L. interrogans が分離されたとの報告がある ${ }^{12)} 。$ それらの 3 株中, 1 株の血清型はCopenhageni あるいは Icterohaemorrhagiae であったが, 残り 2 株はいずれも Hebdomadis と同定された。今回分離されたレプトスピラ
の血清型は不明であるが, 今後パルスフィールド電気泳動 法, flaB 遺伝子の解析, 抗血清を用いた凝集反応などを実 施することなどより型別する必要がある。

全 259 頭について PCR 法を用いてレプトスピラ DNA の検出を試みたところ 60 頭 (23.2\%) が陽性を示した。 肝臓で陽性を示したものが 60 例中 26 例（43.3\%）であっ たのに対し腎臓，尿で陽性を示したものが 60 例中 47 例 (78.3\%) であり，菌分離と同様の傾向を示した。したがっ てレプトスピラの多くが腎蔵に保菌され尿中に排菌される ことにより，環境が污染され，人や動物の感染原因となる ものと考えられた。レプトスピラ DNAの検出で陽性のも のが 259 頭中 60 頭（23.2\%）であったのに対し菌分離陽 性のものは 259 頭中 10 頭 (3.9\%) であった。

総頭数 255 頭について 11 種の血清型のレプトスピラを 用いて凝集反応行った。その結果，63 頭（24.5\%）でい ずれかの血清型に対しての抗体が確認され，レプトスピ ラが北海道のアライグマの間に広く浸潤していることが 明らかとなった。小泉ら ${ }^{12)}$ は, 神奈川県の野生アライグ マのレプトスピラ抗体陽性率を $12.9 \%$, 主たる血清型は Copenhageni あるいは Icterohaemorrhagiae と報告している。 本研究においてはより高い陽性率を示し, 北海道における 浸潤の程度が高いことが判明した。また，陽性を示した主 たる血清型は Autumnalis であり, 神奈川県とは異なって いたが地域的な差と考えられた。また, 今回の調査では日 本ではあまり見られない血清型 Pomona や Pyrogenes に対 する抗体を保有する例がみられた。海外ではアライグマが 血清型 Pomona に対する抗体を保有していたとの報告があ $り^{4,14,15,23)}$ ，アライグマが日本に持ち込んだ可能性も否定 できない。凝集反応の結果から, これらの血清型について, 同地域における他の野生動物の抗体調査を実施する必要が 
ある。PCRの結果と同様に，成獣のほうが幼獣よりも陽 性率が高かった。成獣のほうがレプトスピラに污染された 環境に接する機会がより多かったためと考えられる。また， 胆振地方に打ける PCR 陽性率と抗体陽性率が他地域に比 較し高かった。胆振地方に掞けるアライグマの密度が高く, 陽性個体との接触の機会が多かったのではないかとも考え られる。また，湿地帯などのレプトスピラにとって棲息に 適した環境が多いのかもしれない。さらに検討する必要が ある。

日本で生息しているアライグマがどのようにしてレプト スピラに感染するのかについては詳しくわかっていない。 レプトスピラに感染したマウスを慨として与えた実験で, オポッサム，スカンク，レッドフォックスはレプトスピラ に感染するものがいたのに対しアライグマはレプトスピラ に感染しなかったという報告がある ${ }^{19)}$ 。アライグマは食性 の幅が広く，雑食である ${ }^{8,9,10)}$ が，レプトスピラのレゼルボ アであるネズミを捕食することによる感染の可能性は少な いと考えられる。感染動物から排泄された尿などに污染さ れた水や土などの環境との接触が主な感染経路と考えられ る。

アライグマのレプトスピラ症の臨床症状についてはこれ まで報告がなく，その詳細は不明である。今回の調查で用 いたのは臟器と尿であり生前も不明であるが，臟器と尿に はとくに目立った異常は認められなかった。臨床症状につ いては今後の検討課題である。

本研究から, 北海道の石狩・空知・胆振地方のアライグ マにはレプトスピラが広く浸潤していることが確認され た。現在，アライグマは日本の各地で増加しており，人， 犬および家畜などとの接触の機会も増えてきている可能性 がある。日本各地におけるアライグマはレプトスピラを保 有している可能性が十分考えられるため，アライグマから 人，犬および家畜へのレプトスピラ感染の可能性があり， 今後アライグマの増加に対する何らかの対策の必要性が示 唆された。

\section{要 約}

北海道では野生化したアライグマが増加しているが，ア ライグマに拈けるレプトスピラ症の浸潤状況は十分に知ら れていない。今回，北海道中央部で捕獲されたアライグマ についてレプトスピラの浸潤調查を行った。

捕獲されたアライグマ 259 頭中 10 頭（3.9\%）からレプト スピラが分離された。肝臓 2 例 (0.8\%), 腎臟 9 例 (3.5\%), 尿 1 例 $(0.4 \%)$ からレプトスピラが分離された。PCR 法 により 60 頭 (23.2\%)からレプトスピラ DNAが検出された。 肝臟 26 例 $(10 \%)$, 腎臟 33 例 $(12.7 \%)$, 尿 28 例 $(10.8 \%)$ からレプトスピラ DNA が検出された。11 種の血清型のレ
プトスピラを用いて顕微鏡学的凝集反応（MAT）を行っ た。255 頭中 63 頭（24.5\%）でいずれかの血清型に対して の抗体が確認された。その中でも Autumnalisに対して高く， $10 \%$ 以上の陽性率を示した。PCR および抗体調査の結果, 幼獣よりも成獣のほうが，また地域的には胆振地方の陽性 率が高かった。

以上の結果から, 今回捕獲した北海道のアライグマには レプトスピラが広く浸潤していることが明らかになった。 アライグマは急増し，人，犬，家畜などとの接触の機会も 増えてきている。したがって，アライグマからの人，犬， 家畜へのレプトスピラ感染の可能性が危惧された。

\section{引用文献}

1) Amundson, T. E., Yuill, T. M. : Prevalence of selected pathogenic microbial agents in the red fox (Vulpes fulva) and gray fox (Urocyon cinereoargenteus) of southwestern Wisconsin. J. Wildl. Dis., 17, 17-22, 1981.

2) Bradley, K. K. : Leptospirosis. J. Okla. State Med. Assoc., 92, 114-115, 1999

3) Faine, S. : Guidelines for the control of leptospirosis. WHO. 1982; 小西久典, 富田正章 共訳, 吉井善作 監訳 : レプ トスピラ症防疫指針．内田老鶴圃，東京，1987。

4) Falk, V. S. : Leptospirosis in Wisconsin: Report of a case associated with direct contact with raccoon urine. Wisconsin Med. J., 84, 14-15, 1985.

5）古谷徳治郎ら：豚の早死産胎児における PCR および 抗体検査によるレプトスピラ浸潤調查. 日獣会誌, 59, 459-463, 2006.

6) Gravekamp, C. et al. : Detection of seven species of pathogenic leptospires by PCR using two sets of primers. J. Gen. Microbiol., 139, 1691-1700, 1993.

7) Hamir, A.N. et al. : The prevalence of interstitial nephritis and leptospirosis in 283 raccoons (Procyon lotor) from 5 different sites in the United States. Can. Vet. J., 42, 869871, 2001.

8）北海道石狩支庁アライグマ被害検討協議会:アライグ マによる農業等被害防止の手引き。北海道石狩支庁, 1999.

9）北海道環境生活部環境室自然環境課: 平成 15 年度了 ライグマ対策行動計画．北海道環境生活部， 2003.

10）北海道空知支庁 農業振興部農務課企画調整係, 地域 政策部環境生活課自然環境係：「アライグマをはじめ とする移入動物問題を考える」フォーラム報告書. 北 海道空知支庁， 2000 .

11）川端宽樹，渡邊治雄：レプトスピラ症。日本臨床, 57, 191-193, 1999. 
12) Koizumi, N. et al. : Isolation and characterization of Leptospira spp. from raccoons in Japan. J. Vet. Med. Sci., 71, 425-429.

13) Levett, P. N. et al. : Surveillance of leptospiral carriage by feral rats in Barbados. West Indian Med. J., 47, 15-17, 1999.

14) McGowan, J. E. and Karstad, L. : Field and laboratory studies of skunks, raccoon and groundhogs as reservoirs of Leptospira pomona. Can. Vet. J., 6, 243-252, 1965.

15) Mikaelian, I. et al. : Leptospirosis in raccoons in Quebec: 2 case reports and seroprevalence in a recreational area. Can. Vet. J., 38, 440-442, 1997.

16) Mitchell, M. A. et al. : Serologic survey for selected infectious disease agents in raccoons from Illinois. J. Wildl. Dis., 35, 347-355, 1999.

17）森 守:レプトスピラ症の疫学と予防について. 化学 療法の領域, 8, 646-652, 1992.

18) Reilly, J. R. : The raccoon as a wildlife reservoir of Leptospira canicola. NY Fish Game J., 1, 220, 1954.

19) Reilly, J. R. et al. : Experimentally induced predator chain transmission of Leptospira grippotyphosa from rodents to wild marsupialia and carnivore. Am. J. Vet. Res., 31, 14431448, 1970.

20) Rapley, W. A. et al. : A natural outbreak of leptospirosis in a captive black-tailed deer (Odocoileus hemionus columbianus) herd and in Dall's sheep (Ovis dalli) at the Metropolitan Toronto zoo. Pro. Am. Assoc. Zoo Vet. Annu. Meet, 23, 115-120, 1981.

21) Richardson, D. J. and Gauthier, J. L. A. : Serosurvey of leptospirosis in Connecticut peridomestic wildlife. Vector Borne Zoonotic Dis., 3, 187-193, 2003.

22) Roth, E. E. et al. : Isolation of Leptospira canicola from skunks in Louisiana. Pub. Health Rep., 76, 335-340, 1961.

23) Schnurrenberger, P. R. et al. : Leptospirosis: long-term surveillance on an Illinois farm. Am. J. Epidemiol., 92, 223-239, 1970.

24) Shotts Jr. E. B. et al. : Leptospirosis in selected wild mammals of the Florida panhandle and southwestern Georgia. J. Am. Vet. Med. Assoc., 167, 587-589, 1975.

25）柳原保武：レプトスピラ症. 木村哲, 喜田宏 編 改 訂版人獣共通感染症, 324-330, 医薬ジャーナル社, 大阪, 2011. 